\title{
Book Review: The Other Slavery: The Uncovered Story of Indian Enslavement in America
}

\author{
Emily A. Willard \\ The University of Washington
}

Follow this and additional works at: https://digitalcommons.usf.edu/gsp

\section{Recommended Citation}

Willard, Emily A. (2018) "Book Review: The Other Slavery: The Uncovered Story of Indian Enslavement in America," Genocide Studies and Prevention: An International Journal: Vol. 12: Iss. 3: 187-189.

DOI:

https://doi.org/10.5038/1911-9933.12.3.1612

Available at: https://digitalcommons.usf.edu/gsp/vol12/iss3/19

This Book Review is brought to you for free and open access by the Open Access Journals at Digital Commons @ University of South Florida. It has been accepted for inclusion in Genocide Studies and Prevention: An International Journal by an authorized editor of Digital Commons @ University of South Florida. For more information, please contact digitalcommons@usf.edu. 


\title{
Book Review: The Other Slavery: \\ The Uncovered Story of Indian Enslavement in America
}

\author{
Emily A. Willard \\ The University of Washington \\ Seattle, Washington, USA
}

\begin{abstract}
The Other Slavery: The Uncovered Story of Indian Enslavement in America
Andrés Reséndez

Boston \& New York, Houghton Mifflin Harcourt, 2016

431 Pages; Price: \$15.99 Paperback
\end{abstract}

Reviewed by Emily Willard

University of Washington

In his book The Other Slavery: The Uncovered Story of Indian Enslavement in America, Andrés Reséndez documents the little-known history of slavery of indigenous peoples in the Americas, focusing specifically on the geographic expansion of slavery in North America from the early 1500s, starting in the Caribbean, moving to Mexico, and then to western United States through the mid 1900's. As a historian, Reséndez chronicles not only an understudied part of the history of the Americas, but also provides an incisive exploration of the workings of genocide. ${ }^{1}$ Readers are likely familiar with the argument in Jared Diamond's book Guns, Germs, and Steel: The Fates of Human Societies, in which he argues that indigenous peoples of the Americas were mostly killed out by diseases, particularly smallpox. ${ }^{2}$ Through meticulous archival research and revisiting early texts about European conquest of the western hemisphere, Reséndez offers a compelling alternative argument to understanding the genocide of indigenous peoples in the Americas.

While acknowledging that slavery existed in the Americas prior to European colonization, Reséndez's book places much more responsibility of native genocide on European conquistadors and slave traders, not "weak immune systems." For example, Reséndez argues that the vast population decline of indigenous peoples in the early years of the conquest can be attributed to the horrific conditions of enslavement of indigenous people to mine gold in the Caribbean. Smallpox only came later when large percentages of the population were already dead. Whereas populations in Europe that were decimated by diseases such as the Black Plague could bounce back naturally, indigenous peoples of the Americas could never bounce back naturally because of the harsh conditions of the massive slave trade. ${ }^{3}$ To be sure, Reséndez does not argue against the impact of the spread of disease on the decimation of indigenous populations in the Americas, he argues the importance of understanding the "synergistic relationship" between slavery and epidemics of disease. $^{4}$

Reséndez explains that one of the reasons slavery of indigenous people has been less understood is that it was illegal, so often operated in the shadows of the well-studied slavery of African and African-descent peoples in the Americas. He argues that "one of the most revealing aspects of this other slavery is that since it had no legal basis, it was never formally abolished like African slavery." ${ }^{5}$ Through meticulous archival research and revisiting historical texts from the age of the conquest and through the European settlement of the western United States, Reséndez pieces together information about how indigenous people were owned, sold, and traded by Europeans, but also by each other. One of his objectives, Reséndez argues, is that a better understanding complex systems of this "other slavery" is important because "a similar multiplicity of coercive arrangements is still prevalent today in what is often called 'the new slavery'...in the contemporary trafficking of humans."

\footnotetext{
${ }^{1}$ Andrés Reséndez, The Other Slavery: The Uncovered Story of Indian Enslavement in America (Boston: Houghton Mifflin Harcourt, 2016), 9.

${ }^{2}$ Jared M. Diamond, Guns, Germs, and Steel: The Fates of Human Societies (New York: Norton, 2005).

${ }^{3}$ Reséndez, The Other Slavery, 45.

${ }^{4}$ Ibid., 5, 45 .

${ }^{5}$ Ibid., 8 .

${ }^{6}$ Ibid., 11.

Emily A. Willard. "Book Review: The Other Slavery: The Uncovered Story of Indian Enslavement in America." Genocide Studies and Prevention 12, 3 (2018): 187-189. @2018 Genocide Studies and Prevention.

https://doi.org/10.5038/1911-9933.12.3.1612
} 
Elucidating these key differences between systems of slavery lies at the root of how this book contributes to understanding why and how enslavement of indigenous people was used as a tool to carry out genocide. Reséndez defines key difference between the systems of slavery, beyond just legality and illegality, including the motivations for enslavement, percentage of the population enslaved, the results of enslavement, who was being enslaved, and the movements to abolish slavery.

Within this nuanced narrative, he also explains the details of different types of indigenous slaves, such as slaves of war, and captured (ransomed) slaves, ${ }^{7}$ as well as different systems of enforced labor, such as encomiendas (people were forced to pay a tribute to Spanish officials, ${ }^{8}$ and were allowed to live in own communities and travel to mines for work), repartimientos (remunerated, but compulsory work ${ }^{9}$, debt peonage (forced to work off debt), and the mita (forced, salaried work or "draft labor"). ${ }^{10}$

Indigenous slavery offered a kind of gendered "mirror image" to African slavery. While African slavery revealed a preference for men (who outnumber women two to one) indigenous slaves tended to be women and children. The motivation for enslaving indigenous people were to convert them to Christianity, and integrate them into mainstream European colonial society, whereas enslaved African people were seen as separate and sub-human. Enslavement of indigenous peoples often resulted in death, and this process of either assimilation or death is what Wolfe would argue is the settler-colonial state's "logic of elimination."11

The book clearly sheds light on a relatively unknown history of the Americas, providing compelling arguments for how it has fundamentally formed colonial and post-colonial America. One of the many strengths of this book is that in the telling the history of "the other slavery," Reséndez does not shy away from telling a full and complicated history of the systems of enslavement in the Americas, particularly the fact that many European slavers built upon existing systems of slavery that existed within native communities prior to European conquest and colonization. ${ }^{12}$ Additionally, Reséndez writes of the impact of the Spanish inquisition, and that many of the European slavers were Jewish people who used the economic promises of the slavery system as a way to leave Europe for the New World in an attempt to more safely live abroad. ${ }^{13}$ Reséndez careful research and depth of narrative provides for an unfolding of the complicated and multiple layers of oppression at the time.

His research draws a broad arc, showing connections between past systems of slavery and how they have morphed and continue to today. Reséndez writes of the movement to abolish African slavery, explaining that during the reconstruction period, the government was forced to define precisely what the meaning and extent of the thirteenth amendment was, and whether or not it also abolished Indian slavery. ${ }^{14}$ Reséndez explains that the historical record is unclear regarding exactly when Indian slavery was abolished, and he argues continued well into the twentieth century. ${ }^{15}$

This book provides several compelling arguments backed up with rigorous archival research, though there are areas which could have been further developed. Reséndez clearly intends to focus on indigenous slavery and is not a comparison between indigenous slavery and African slavery, however it lacks a clearer connection about how the two systems of African and indigenous enslavement interacted with each other in order to fully understand the nature of and implications of the system of enslavement of indigenous people. For example, the way that peoples from Africa were brought in to replace the population of enslaved workers of the indigenous population that

\footnotetext{
${ }^{7}$ Ibid., 62.

${ }^{8}$ Ibid.

${ }^{9}$ Ibid., 71.

${ }^{10}$ Ibid., 124.

${ }^{11}$ Patrick Wolfe, "Settler Colonialism and the Elimination of the Native," Journal of Genocide Research 8, no. 4 (2006), 387409.

${ }^{12}$ Reséndez, The Other Slavery, 64.

${ }^{13}$ Ibid., 96-98.

${ }^{14}$ Ibid., 301.

${ }^{15}$ Ibid., 314.
} 
was dying out as a result of the harsh conditions. An important part of this conversation that Reséndez also did not adequately address is how, while Bartolome las Casas argued against the enslavement of indigenous peoples, for part of his life he advocated for the enslavement of Africans.

Additionally, while Reséndez notes a different times the nonexistence of written, detailed accounts by Indian slaves, ${ }^{16}$ he finds the testimony of several people in the records of Spanish court cases elucidating a rare view into the lived experiences of Indian slaves. That being said, Reséndez seems to rely entirely on archival and written records, usually written from the view point of European settlers either as slavers, or observers, to understand the experiences of indigenous people. In one instance, he references "oral traditions of Hopi villages - which are corroborated at least in part by documentary information,"17 suggesting the higher value placed on written versus oral histories. While there may be a disciplinary argument for the centralizing of written records, it seems that a project focusing on the experience of indigenous people should ideally include much more from the perspective of indigenous people themselves. Further research could include a more comprehensive study of oral traditions of indigenous peoples about their own past, including experiences of slavery.

Overall, Reséndez provides a nuanced and well-researched history of a previously unknown system of Indian slavery, providing a compelling argument for an alternative cause of indigenous genocide in the Americas.

\footnotetext{
${ }^{16}$ Ibid., 49.
}

${ }^{17}$ Ibid., 166. 